УДК 340.12

DOI https://doi.org/10.32837/pyuv.v0i1(30).508

\author{
H. В. Марущак \\ orcid.org/0000-0001-9636-6274 \\ кандидат юридичних наук, доцент, \\ доцент кафедри теорії та історії держави і права, конституційного права \\ Національного університету «Чернігівська політехніка»
}

\title{
РОЗУМІННЯ ПРАВОСВІДОМОСТІ ТА СУТНОСТІ ДЕРЖАВИ У ТВОРЧОСТІ І. О. ІЛЬЇНА
}

Постановка проблеми. Ще сто років тому питання про державу визнавалося науковцями, письменниками та філософами одним із найскладніших, важких і чи не найбільш заплутаних $[1$, c. 3]. Держава є одним із видів складноорганізованих, багатоаспектних, багаторівневих соціальних систем і охоплює різні сфери людського буття. Саме тому вона є об'єктом дослідження різних наук: політології, соціології, філософії, економічної теорії, психології та багатьох інших. Вона є одним із головних об'єктів дослідження і в юриспруденції. Насамперед це стосується загальної теорії держави і права, для якої характерним є підхід до розуміння держави як цілісного системного політико-правового явища.

Разом із тим залишається низка запитань, які виникають у зв'язку з дослідженням цього феномена: що лежить в основі вказаного явища? В чому сутність держави? В якій формі держава існує? Що таке політика держави? Що таке державна влада і яким чином вона реалізується? Для відповіді на ці та інші запитання, для більш глибокого і повного розуміння поняття «держава» доцільно, на думку автора, звернутися до аналізу змісту цього поняття в працях видатного представника філософської та юридичної думки минулого століття I.O. Ільїна.

Метою статті є з'ясування сутності та змісту філософсько-правової концепції І.О. Ільїна, аналіз його поглядів на поняття правосвідомості, сутності і значення права і держави, проблеми влади, людської свободи та гідності.

Політичні погляди I.О. Ільїна, думки про державний устрій і форми влади зазнали протягом його життя значної еволюції. Концепція «Бога, який страждає», роздвоєність, суперечливість якого прирікає світ і людину на вічний розбрат i боротьбу, виявилася напрочуд точним вираженням суспільної ситуації початку XX ст. $з$ її непримиренністю, жорстокістю, готовністю йти до кінця в захисті своїх ідеалів [2, с. 107]. I.О. Ільїн, за свідченнями сучасників, володів принциповим, жорстким характером і непримиренно відстоював свої переконання, тому багато опонентів I.О. Ільїна навіть називали його «більшовиком» [2, с. 121].

Авторитетний дослідник творчості I.O. Ільїна I.I. Євлампієв зазначає, що негативні риси його характеру і деякі помилкові положення його філософської системи безпосередньо пов'язані з глибоким переконанням у наявності однозначного і чітко проведеного кордону між добром і злом у нашому світі, що призводило до своєрідного морального максималізму, не визнання «напівтонів» і «світлотіней» у людських відносинах і в моральній орієнтації [2, с. 122].

I.O. Ільїна з упевненістю можна назвати видатним пророком XX ст. [3, с. 6]. Філософ права за спеціальністю він став вченим-споглядачем, творцем концептуальних праць про культуру i дух народу, його соціальну психологію, дослідником подій XX ст. і їх наслідків для цивілізації. Широта охоплення проблем суспільства та глибоке вкорінення у національне буття дозволили йому побудувати вражаючі соціальні прогнози, неперевершені й нині. Думки видатного філософа, правника, висловлені ним ще сто років тому, не втрачають своєї актуальності і в умовах зміни соціальної структури суспільства, маргіналізації значної частини населення, зміни системи цінностей і картини світу, спотворення розуміння природи істинної влади.

Виклад основного матеріалу дослідження. I.O. Ільїн ввів у науковий обіг поняття «нормальна» або «здорова правосвідомість», тобто правосвідомість в істинному розумінні слова, підкресливши, що існує i «ненормальна й нездорова правосвідомість», якою здебільшого живуть як юристи, так і інші громадяни. Саме з позиції нормальної правосвідомості правознавець запропонував по-новому поглянути на сутність і значення права і держави.

Розкриття сутності правосвідомості I.О. Ільїн розпочав із роздумів про те, ким є людина, чим вона живе і до чого вона покликана. Перш ніж пізнати навколишне, ми повинні пізнати себе. Мислитель стверджував, що людина за своєю суттю трьохмірна, складається з духу, душі і тіла. Слід зазначити, що подібний погляд на людину у І.О. Ільїна склався під впливом вчення православної церкви про людину. Тільки життя душі і тіла відповідно до духу, тобто спрямованість до Вищого, Досконалого, Істинного і Прекрасного, здатна забезпечити повноту буття і справжне щастя для людини. Коли дух володіє душею і тілом, 
тоді людина може створювати гармонію і порядок у суспільному житті. В іншому випадку право і держава стають знаряддям зла.

Державу, на думку I.О. Ільїна, необхідно розглядати крізь призму нормальної правосвідомості. «Якщо право безсило і безглуздо поза правосвідомістю, то держава принизлива, ефемерна і мертва поза державним способом мислення» [4, с. 259].

Державний спосіб мислення вбачався I.O. Ільїним як різновид правосвідомості. «Об’єктивна природа держави визначається її вищою метою, iii єдиним і незмінним завданням. Це завдання полягає в огорожі і організації духовного життя людей, які належать до цього політичного союзу. Огородження духу полягає в забезпеченні всьому народу і кожному індивіду його природного права на самобутнє визначення себе в житті, тобто права на життя, і до того ж на гідне життя, зовні вільне і внутрішньо самостійне» [4, с. 267].

Сутність держави полягає в тому, що всі їі громадяни мають одну мету і один спільний інтерес. Загальна мета всіх громадян полягає в тому, щоб організувати правопорядок - створити єдиний союз iз єдиною загальною правовою владою і єдиною спільною системою права. Саме в цьому, на думку I.O. Ільїна, і складається організуюче завдання держави, у здійсненні якого всі однаково зацікавлені. У виявленні такої солідарності і в служінні полягає мета політичної діяльності [4, с. 268].

Пильну увагу I.О. Ільїн приділяв проблемам влади. Він сформулював шість аксіом, порушення яких, на його думку, могло б призвести до спотворення, ослаблення або зловживання владою:

1. Державна влада не може належати нікому, крім правового повноваження.

2. Державна влада в межах кожного політичного союзу має бути єдина.

3. Державна влада завжди повинна здійснюватися кращими людьми, які відповідають етичному та політичному цензу.

4. Політична програма може включати в себе тільки такі заходи, які переслідують загальний інтерес.

5. Програма влади може включати в себе тільки здійсненні заходи або реформи.

Державна влада принципово пов'язана розподільною справедливістю, але вона має право і обов'язок відступати від неї тоді, коли цього вимагає підтримка національно-духовного і державного буття народу [4, с. 295-308].

«Ці правила, - зазначав I.О. Ільїн, - можуть бути названі законами тому, що вони вказують постійний і необхідний порядок, який людям слід здійснювати в їх діяльності. Зрозуміло, що «сталість» цього порядку полягає не в тому, що «так завжди буває»: люди можуть дотримуватися правил, але можуть і не дотримуватися їх, і в дійсності вони часто їх не дотримуються. «Сталість» означає, що люди завжди повинні діяти так, а не інакше і що вони будуть не праві кожного разу, як тільки порушать ці правила. Так само «необхідність» цього порядку полягає не в тому, що «інакше не може бути», а в тому, що дотримання цих законів є єдиним шляхом, при якому люди будуть праві. Той, хто поводиться відповідно до закону обов'язку, не може бути неправий - ось сенс «необхідності» [4, с. 51]. Такі закони правильної, належної поведінки він називав нормами. Отже, норма є судженням, яке встановлює відомий порядок як належний, це є виражене в словах правило кращого [4, с. 52]. Але що ж є краще?

I.O. Ільїн стверджував: «Перш ніж встановити норму, необхідно мати правильне і чітке уявлення про те, що є краще. Той, хто намагається встановити правило мислення, повинен дослідити, що $є$ «краще» в мисленні, тобто що таке істина; хто шукає правило для художньої творчості, той повинен вирішити питання про те, що є краще в мистецтві, тобто що таке краса; хто прагне встановити правило морально праведного життя, той повинен дослідити сутність добра; а той, хто встановлює правову норму - в чому полягає сутність справедливості» $[4$, с. 53$]$.

I.O. Ільїн розмірковував про те, що держава за своєю основною ідеєю є духовним союзом людей, які володіють зрілою правосвідомістю і владно стверджують природне право у братському, солідарному співробітництві. «З одного боку держава живе правосвідомістю людей, а суттєвою рисою правосвідомості є здатність до самоврядування; тому держава зводиться до самоврядування народу. Однак, єдина і об'єктивна мета держави настільки висока і вимагає від громадян настільки зрілої правосвідомості, що народи, які здійснюють цю мету, виявляються нездатними до самоврядування» [4, с. 277].

Проблема вирішується через поєднання елементів управління і самоврядування в державі, виходячи із зрілості народної правосвідомості. Знайти цю історично найкращу комбінацію 3 «солідарного самоврядування та пануючої опіки» означає правильно вирішити проблему організації державної влади, що відбиває існуючий рівень народної правосвідомості. Будь-яка реформа, стверджува I.О. Ільїн, невідповідна зі станом народної правосвідомості, може виявитися безглуздою і згубною для держави. Єдиним шляхом до реформ є поступове виховання правосвідомості, що є одним із основних завдань державної влади [4, с. 277].

Природа державної влади визначається тією метою, заради якої вона створюється, а ця мета є метою самої держави. Це означає, що політична влада служить Батьківщині, тобто національному духовному розквіту: у цьому служінні вона знаходить, формулює, захищає і забезпечує природне 
право, надаючи йому форму позитивного правопорядку. Політичне владарювання покладає на людину найбільшу відповідальність: владарюючий за покликанням є законодавцем природної правоти, тому він має бути здатний до предметного розуміння духу і права, має володіти розвиненою та поглибленою правосвідомістю [4, с. 280].

Історичні держави, повільно і поступово допускаючи маси до публічної діяльності, керуються інстинктом самозбереження, інакше політичний союз ризикує своїм існуванням [4, с. 284-285]. Політична мудрість полягає в тому, щоб підтримувати режим опіки тільки в міру дійсної необхідності i в той же час енергійно працювати над подоланням політичної нездатності мас, виховувати в масах дух корпоративного самоврядування і закріплювати цей дух відповідною державною формою.

Завдання державної опіки полягає не в тому, щоб підтримувати опікуваного в стані духовного неповноліття, осудності, а в тому, щоб виховувати опікуваного, повідомляючи йому здатність до вольового самоприборкування і самодисциплінування - здатність до самоопікування. Держава сильна і гідна не тоді, коли влада тягне населення до принципу верховенства права проти його волі, нав'язуючи патріотичну солідарність за допомогою страху і страт, а тоді, коли в народі живе дух державного патріотизму і політичного волонтерства [4, с. 286]. На думку І.О. Ільїна, знайти цю історично найкращу комбінацію з «солідарного самоврядування та пануючої опіки" означає вирішити проблему організації державної влади [4, с. 281].

I.O. Ільїн у своїх роботах дає обгрунтування людської свободи, духовності людини, справедливості. «Є два різних розуміння людини, - писав I.O. Ільїн, - духовне і недуховне [5, с. 254]. Духовне бачить в ній творчу істоту, живу посудину Духа Божого. В такому розумінні життя людини - процес самобудівництва, тобто будівництва характеру, облаштування життєвого простору. Потреба в приватній власності є невід'ємною частиною творчої духовної істоти. Роль держави двояка: вона може зберегти і підтримати людину в її духовній самостійності і господарській ініціативі, а може шляхом експропріації перетворити людину в залежного і беззахисного раба. Останнє можливо при недуховності розуміння людини як м'язового центру. Держава в такому випадку стає машиною для примусу, яка зводить все приватне життя до мінімуму. Майнова незалежність, особливо власність на засоби виробництва, сприймається негативно і скасовується.

Таке розуміння людини і держави породжує антиутопію - комуністичний режим. I.O. Ільїн пропонує детальний аналіз хибності цього шляху:

1. Комунізм протиприродний, оскільки не сприймає індивідуального способу життя людини.
2. Комунізм протисуспільний, оскільки намагається створити державу, засновану на класовій ненависті.

3. Комунізм здійснює розтрату сил.

4. Комунізм можна здійснити тільки терором, тому ніякого

відношення до свободи цей режим не має.

5. Комунізм не призводить до справедливості.

6. Комунізм не звільняє людей, він вводиться примусово і насильно, скасовує всі життєві права і свободи [5, с. 259-263].

На думку I.О. Ільїна, комунізм не тільки не компрометує ідею приватної власності, а й остаточно iï реабілітує. Обгрунтування приватної власності I.О. Ільїн пов'язує з поняттям свободи. Приватна власність - це життєва необхідність, «кожній особі слід надати особисту, приватну власність: цього вимагає ії свобода, це необхідно для її дійсності». Про це І.О. Ільїн писав у своїй книзі «Філософія Гегеля як вчення про конкретності Бога і людини» [6, с. 321].

Особливий інтерес викликає концепція гідності особи I.O. Ільїна, який уже в своїх ранніх працях підкреслював самоцінність людської особистості, своєрідність, одиничність людини й індивідуальний розвиток її щиросердного і духовного життя. Вчений зазначав, що саме повага до себе як духу лежить в основі життєвої боротьби за суб'єктивне право [4, с. 319]. «Почуття власної гідності встановлює в цій боротьбі дві грані: грань, від якої починається неможливість поступатися своїми правами, - такі всі права особистої свободи, грань, від якої починається неможливість наполягати на своїх правах, - такі всі «неприродні», несправедливі повноваження, принизливі для інших, а тому принизливі і для самого уповноваженого. $€$ права, від яких не можна відмовитися, зберігаючи повагу до свого духу, але є права, від яких не можна не відректися з почуття власної гідності. I кращі люди не раз засвідчили вірність цьому і словом, і ділом, і смертю» [4, с. 319].

Під почуттям власної гідності I.O. Ільїн розумів необхідний і справжній вияв духовного життя. «Воно є знаком того духовного самоствердження, без якого немислимі ні боротьба за право, ні політичне самоврядування, ні національна незалежність. Громадянин, позбавлений цього почуття, - політично недієздатний; народ, який не керується ним, - приречений на тяжкі історичні приниження» $[4$, с. 311$]$.

Вчений підкреслював ту важливу роль, яку відіграє гідність людини не тільки в їі житті, але й у житті держави. Він вважав, що, не поважаючи себе, людина не поважає і громадянина в собі. Не розуміючи своєї духовної гідності, вона не бачить духовної гідності ні в інших громадянах, ні в державі. Людина сприймає чужу гідність як чужу силу і бачить в ній або своє знаряддя, 
або свою небезпеку. Такий індивід до державної влади відчуває не довіру і повагу, а покірність. На підставі цього I.O. Ільїн дійшов висновку, що народ, який не вміє поважати свою духовну гідність, створює недолугу владу, виношує хворе самопочуття і хвору ідеологію [4, с. 330].

Філософська концепція «очевидності» - підсумок його багатогранної філософської діяльності. Сучасне людство, стверджував I.О. Ільїн, переживає глибоку кризу; в своїй основі це криза духовна, тобто руйнація корінних духовних начал людського буття. Найважливіше завдання полягає в тому, щоб відновити і відродити ці основи, для чого необхідно глибоко проникнути в їх справжню природу, зрозуміти особливості засвоєння і трансляції духовних цінностей у суспільстві, роль різних соціальних інститутів (сім'ї, нації, держави) в цьому процесі.

Поки людина живе, вона має виховувати i зміцнювати свою силу судження. Їй необхідно організовувати свій внутрішній світ і зовнішне середовище, яке її оточує. Їй необхідний лад і порядок. Упорядковувати означає владно втручатися в хаотично-випадковий потік життєвих змістів, розділяти, виокремлювати, вибирати соприналежне і встановлювати нові, життєво необхідні зв'язки, нову соприналежність речей. Організовувати означає відрізняти істотне від несуттєвого i надавати істотному ваги і значення; це означає встановлювати переважання, підпорядкування і зчленування, розподіляти функції, обов'язки та повноваження, створюючи цілісний і життєздатний організм (селянське господарство, управляюче відомство, фабрику, армію, школу, розумовий організм книги, художній організм картини, симфонії, драми). В основі всього цього лежить процес судження, як необхідне і творче вираження життя [7, с. 438].

Висновки. I.O. Ільїн - один із найвідоміших представників філософської думки кінця XIX початку XX століть. Проте внесок I.O. Ільїна у світову культуру $є$ й досі не до кінця оціненим. Залишаються маловідомими його праці в сферах історії філософії, політичної і релігійної філософії, теорії права і держави. Особливої ваги і значення для сучасних науковців набувають його ідеї про правосвідомість і державу, державну ідею, патріотизм, а дещо взагалі можна сприймати як пророцтва.

Варті уваги дослідження I.О. Ільїна про духовно здорову правосвідомість, що може сприяти перетворенню права, яке часто приховує брехню, насильство, розбрат, бунт і війну. Актуальними є слова I.O. Ільїна про те, що сучасний світ переживає глибоку кризу - релігійну, духовну i національну. Такий погляд поступово завойовує позиції в світі. Він особливо актуалізується в умовах, зумовлених проблемами сучасного глобалізованого світу.
Отже, вчення I.O. Ільїна надзвичайно актуальні і в наші дні, коли в державі процвітає правовий нігілізм, а правосвідомість знаходиться на надзвичайно низькому рівні. Щоб докорінно змінити ситуацію, яка склалася, потрібно напружено працювати не одному поколінню українців, насамперед морально орієнтованих юристів-професіоналів. Вихід із кризи необхідно знайти. «Цей вихід треба знайти кожному, треба самому почати існувати по-новому». Це єдиний шлях. Іншого немає.

\section{Jimepamypa}

1. Ленин В.И. О государстве. Москва : Госпилитиздат. $1950.24 \mathrm{c}$.

2. Евлампиев И.И. Божественное и человеческое в философии Ивана Ильина. СПб., 1998. 296 с.

3. Шарипов А.М. Русский мыслитель Иван Александрович Ильин. Творческая биография. М. : Изд-во Главархива Москвы «Деловой ритм», 2008. $304 \mathrm{c.}$

4. Ильин И.А. Собрание сочинений: в 10 т. / сост., вступит. ст. и коммент. Ю.Т. Лисицы. Москва : Русская Книга, 1993-1999. Т. 4: [Понятия права и силы; Общее учение о праве и государстве; О сущности правосознания; О монархии и республике; Из лекций «Понятия монархии и республики»]. Москва : Русская книга, $1994.624 \mathrm{c}$.

5. Ильин И.А. Собрание сочинений: в 10 т. / сост., вступит. ст. и коммент. Ю.Т. Лисицы. Москва: Русская Книга, 1993-1999. Т. 1: [Путь духовного обновления; Основы христианской культуры; Кризис безбожия]. Москва : Русская книга, 1993.400 с.

6. Ильин И.А. Философия Гегеля как учение о конкретности Бога и человека. СПб., 1994. С. 320.

7. Ильин И.А Собрание сочинений: в 10 т. / сост., вступит. ст. и коммент. Ю.Т. Лисицы. Москва : Русская Книга, 1993-1999. Т. 3: [Шлейермахер и его три речи о религии; Религиозный смысл философии; Три речи; Я вглядываюсь в жизнь: Книга раздумий; Поющее сердце: Книга тихих созерцаний; Путь к очевидности]. Москва : Русская книга, 1994. 592 с.

\section{Анотація}

Марущак Н. В. Розуміння правосвідомості та сутності держави у творчості I. O. Ільїна. - Стаття.

у статті аналізується зміст правових і політичних поглядів I.О. Ільїна на поняття правосвідомості, сутності і значення права і держави, проблем влади, людської свободи та гідності. Показано, що суть філософсько-правової концепції I.О. Ільїна полягає у виділенні «нормальної» або «здорової правосвідомості», тобто правосвідомості в істинному розумінні слова. Саме через правосвідомість I.O. Ільїн визначав право, державу, її сутність.

Пильну увагу I.O. Ільїн приділяв проблемам влади. Ним було сформульовано шість аксіом, порушення яких, на його думку, могло б призвести до спотворення, ослаблення або зловживання владою. I.О. Ільїн у своїх роботах наводив обгрунтування людської свободи, духовності людини, справедливості. 3 поняттям приватної власності I.O. Ільїн пов'язував обгрунтування свободи. На думку філософа, це життєва необхідність, потреба в приватній власності є невід’ємною частиною творчої духовної істоти. У зв'язку з цим I.O. Ільїн стверджував, що комуністична держава може шляхом експропріації перетворити людину в залежного i беззахисного раба. Держава в такому випадку стає машиною для примусу, яка зводить все приватне жит- 
тя до мінімуму. Майнова незалежність, особливо власність на засоби виробництва, сприймається негативно і скасовується. Таке розуміння людини і держави породжує антиутопію - комуністичний режим. I.O. Ільїн запропонував детальний аналіз хибності цього шляху.

Особливу увагу автор статті присвячує аналізу в творчості I.О. Ільїна людської гідності, під якою філософ розумів необхідний і справжній вияв духовного життя. Вчений підкреслював ту важливу роль, яку відіграє гідність людини не тільки в її житті, але й у житті держави. Він вважав, що, не поважаючи себе, людина не поважає і громадянина в собі. Не розуміючи своєі духовної гідності, вона не бачить духовної гідності в інших громадянах, у державі. На підставі цього I.О. Ільїн дійшов висновку, що народ, який не вміє поважати свою духовну гідність, створює недолугу владу, виношує хворе самопочуття і хвору ідеологію.

Автор статті обґрунтовує актуальність творчості I.O. Ільїна в сучасних умовах глобалізованого світу. Стверджує, що вчення I.O. Ільїна набуває особливої ваги і значення в наші дні, коли в державі процвітає правовий нігілізм, а правосвідомість знаходиться на надзвичайно низькому рівні.

Ключові слова: І.О. Ільїн, правосвідомість, держава, право, свобода людини, гідність людини.

\section{Summary}

Marushchak N. V. Understanding of the legal consciousness and essence of the state in the works of I. Ilyin. - Article.

The article analyzes the content of legal and political views of I. Ilyin, the concept of legal awareness, the essence and meaning of law and the state, the problems of powers, human freedom and dignity. It is shown that the essence of the philosophical and legal concept of I. O. Ilyin is to distinguish "normal" or "healthy legal consciousness", that is, legal consciousness in the true sense of the word. It is through legal awareness that I. Ilyin defines law, the state, and its essence.
I. Ilyin paid close attention to the problems of powers. He formulated six axioms, the violation of which, in his opinion, could lead to distortion, weakening or abuse of power. I. Ilyin in his works provides justification for human freedom, human spirituality, and justice. It is with the concept of private property that I.O. Ilyin connects the justification of freedom. According to the philosopher, this is a vital necessity, the need for private property is an integral part of the creative spiritual being. In this connection, I. Ilyin claims that the Communist state can turn a person into a dependent and defenseless slave by expropriation.

The state in this case becomes a machine for coercion, which reduces all private life to a minimum. Property independence, especially ownership of the means of production, is perceived negatively and rejected. This understanding of man and the state creates a dystopia-the Communist regime. I. Ilyin offers a detailed analysis of the falsity of this path. The author of the article devotes special attention to the analysis of human dignity in the works of I. Ilyin, by which the philosopher understood the necessary and present manifestation of spiritual life. The scientist emphasized the important role that human dignity plays not only in her life, but also in the life of the state.

He believed that if a person does not respect himself, he does not respect the citizen in himself. Not understanding his spiritual dignity, he does not see spiritual dignity either in other citizens or in the state. Based on this, I. Ilyin comes to the conclusion that the people who do not know how to respect their spiritual dignity create a disease of power, nurture a sick state of health and a sick ideology. The author of the article substantiates the relevance of I. Ilyin's work in the modern conditions of the globalized world. Claims that the doctrine of I. Ilyin acquires special weight and significance in our days, when legal nihilism flourishes in the state, and legal awareness is at an extremely low level.

Key words: I. Ilyin, legal awareness, state, law, human freedom, human dignity. 